SH

$363^{\circ}$

. T7

eopy 2 



\title{
FUR SEALS AND THE SEAL FISHERIES
}

\author{
s \\ By Charles H. Townsend \\ Director New Iork Aquarium, Now York City

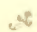

Address before the Fourth International Fishery Congress held at Washington, U. S. A., September 22 to 26, 1908

BULLETIN OF THE BUREAU OF FISHERIES : : : VOL. XXVII, P. 315-322

Document No, $661:: \quad: \quad: \quad: \quad: \quad: \quad: \quad: \quad: \quad: \quad: \quad$ : lesued February, 1910 


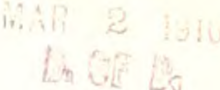

$\therefore$

. 


\title{
FUR SEALS AND THE SEAL FISHERIES.
}

\author{
\& \\ BY CHARIES H. TOWNSEND, \\ Director New Jork Aguarium, New York (ity.
}

$*$

The history of the world's seal fisheries is largely one of wasted resources. Very few sealing industries have been conducted according to methods designed to perpetuate the race. Yet from a commercial point of view, seals are the most important of the carnivorous animals. As a group they are probably also the most abundant of the larger wild mammals at the present time. It is doubtful whether the herds of bison in America and of antelopes in Africa ever exceeded the seals in point of numbers. They are of world-wide distribution, and although the fur-seal fisheries of the North Pacific have received much international consideration during recent years, they were formerly not the only seal fisheries of importance. The pursuit was at one time carried on in the Antarctic regions as well as in the Arctic. The Antarctic sealing grounds have long been exhausted commercially, however.

All seals breed on land or on ice floes, and return, after their migrations, to their accustomed breeding places with great persistence. They can seldom be driven entirely away, stupidly lingering until brought near the point of extermination. So certain are they to return to their breeding grounds that the reestablishment of the differcnt species soon follows the protection of these places. The safeguarding of depleted sealing grounds would, in fact, be a good business proposition even at this late day, if they could be protected under the authority of the various govemments laying claim to such lands.

\section{ANTARCTIC SEALS.}

The various species of Antarctic fur seals (genus Arctocephalus) were found about the southern shores and islands of South Africa, Australia, New Zealand, and the islands of the Antarctic generally. About the close of the eighteenth century there sprang up a traffic in the skins of fur seals, and as the result of the many voyages to those distant regions enormous numbers of the animals were taken. By I830 the supply of fur scals in the southern seas was nearly exhausted. The species exists to-day as mere remnants of the great herds that were once found in those regions. 
In this schling no discrimination was made in the character of the seals taken. All animals whose skins were of any value were slaughtered, and the newly born voung, usually left on the killing sromeds, died of starvation. In the rush to the Antarctic sealing grounds the markets were frequently glutted ancl much of the catch wasted.

The South African fur seal (Avdocephalus delahmdi), frequenting small islands off the west coast of South Africa, became very rare from indiscriminate sealing. It has, during very recent years, been protected by the government of Cape Colony. The vield of skins from this sonrce has been as follows: I902, I, 300: $1903.4,800 ; 1004,7,700 ; 1905.1,231 ; 1906,12,640 ; 1907,16,786 ; 1908,13.649$.

One resort of the genus Arcoaphatus, the Galapagos Islands, lying on the equator, about soo miles west of Ecuador, furnishes an especially striking illustration of wasteful sealing. These seals (Anctocephahs philippi) were taken in important numbers by early voyagers. Between 18,0 and 1882 the rookeries were again visited by scalers, and, as far as shown by the meager records collected from the sealers still living who engaged in this fishery, about 20,000 seals were taken. This is of course a trivial number as compared with the total catch made during that period, the records of which are not available. Later voyages resulted in the killing of all the seals that could be found. At the time of my first visit to the Galapagos Islands, in 1888, I was informed that there were only a few seals remaining, and those about the uninhabited westerly islands of the archipelago.

It was a matter of great surprise when, in 1897 and 1898 , a vessel returned to San Francisco from the Galapagos Islands with a catch of several hundred fur seals. It appears that the few that had escaped the slaughter of the last voyage, fifteen years before, had estublisled themselves on the identical rookcries from which they had been driven, as comparisons of the log books of the vessels showed. Tnknown to anyone, the nucters of a fine herd existed there, which no doubt could have been developed into an important seal fishery if the fact had been known in time to prevent its destruction by raiders. It is probable, indeed, that a few individuals have ecaped this last slaughter, and with the prompt protection of the rookeries by the Government of Ecuador a fishery could yet be established.

Another species of fur seal (Arctocephulus lownscndi), the most northerly offishot of the Antaretic race, formerly inhabited Guadaloupe and other islands off the west coast of Lower Califorma. From the seattered records that have been found it appears that $1,5,000$ seals have been taken there within comparatively recent vears. (The earlier records are not available.) During the writer's risit to Guadaloupe, in 1892 , straggling fur seals were observed about the istand, and specimens obtained proved the species to be new to seience. It 
is possible that there is a sufficient remnant to warrant the belief that the race could be reestablished if the islands were properly protected by the Government of Mexico. The value of fur-seal skins taken in tropical or semitropical localities is, however, small as compared with those from cold climates.

In all the history of Antarctic sealing there is but one chapter of wise management and thought for the future: The Government of Uruguay has, throughout all these years, carefully preserved the fur-seal rookeries of Lobos Island, at the mouth of La Plata River, inhabited by Arclocephalus australis. These small rookeries illustrate the good resulting from the careful protection of the seals upon their breeding grounds. Commercial sealing was carried on at Lobos Island prior to 1820 . The lessees of the island, operating under the direction of the Government of Uruguay, placed upon the Itondon market, from I 873 to $1904,377,033$ skins, or an average of over 13,000 a year, worth in I gor SIOO,OoO. All these were derived from a single island less than $\mathrm{r}$ mile in length. The following data show the yield of skins from Lobos Island during recent years: $1902,12,922$; $1903,10,994 ; 1904,8,349 ; 1905,2,025 ; 1906,8,398$; $1907,4,373$; $1908,2,990$. The Lobos seals are now menaced by pelagic sealers, and some ressels have been seized by the Government of Uruguay.

In I888, when in the Straits of Magellan, I found the fur-seal herds of that region nearly exterminated by the hunters working among the Fuegian Islands. The recent catch from what is called in the trade the Cape Horn region is as follows: I 905, I I , I 90; I $906,13,628 ; 1907,16,786 ; 1908,8,262$.

\section{NORTHERN FUR SEALS.}

The history of Robbin Island, in the Okhotsk Sea, is especially noteworthy. This island is about 600 yards in length and less than 100 yards in width, and yet incomplete records show that more than 60,000 seals have been taken there by raiders since 1870 . A remnant of this herd has remained annually to repopulate the rookery, which at the present time contains little more than $\mathrm{r}, \mathrm{ooo}$ seals and is protected by the Russian Government.

The scattered fur-seal rookeries in the chain of volcanic islands stretching northward from Japan, known as the Kurils, have also been destroyed by raiders during recent years. The history of the extermination of these seals, as furnished to the writer by men who engaged in the slaughter, is exceedingly interesting. Notwithstanding the fact that raids were made year after year, the scattered remnants of the herds still clung to their old breeding grounds. The incomplete records at hand show that more than 25,000 seals were taken from the Kuril Islands by raider's since 1880 . These rookeries were visited by the United States Fisheries steamer Albatross in 1897 , and all the rookeries were found to have been wiped out with the exception of one, upon which there 
were about too seals remaining. It is believed that these will be protected by Japan, to which country they belong. The seal inhabiting Robbin Island and the Kuril Archipelago is now known as Callowinus curilensis.

The only important strongholds of the diminishing northern fur seals to-day are the Pribilof and Commander islands, in Bering Sea. The species established on the Commander Islands is Callorhinus ursinus, while that breeding on the Pribilofs is Callorhinus alascamus. Although the two species breed upon islands lying in the same latitude and less than $\mathrm{I}$, ooo miles apart, there is no commingling. The former migrates sonthwestward in winter along the Asiatic coast, while the latter migrates sontheastward along the American coast.

Upon the discovery of the fur-seal islands of Bering Sea, more than a century ago, seals were found in great multitudes. Fior many years they were killed indiscriminately, but the Russian Government finally took charge of then and directed the fisheries in such a way that they were regularly productive. The Pribilof Islands in the twenty years after the accession of Alaska vielded more than \$7,000,000, the price paid for the entire District. About twenty-five years ago the practice of pelagic sealing-the killing of seals in the open seadeveloped into an extensive industry, since which time the supply of seals has steadily decreased.

Although during the winter months the fur-seal herds migrate into the Pacific Ocean, they are in summer located on their anciently established breeding places in Bering Sea. The fishery is conducted under government supervision, and a certain number of seals may be killed on the islands, selection being made in accordance with the natural habits of the aninals. Fur seals are highly polygamous, and the rookery communities are divided up into harems. The males arrive at the islands and fight furiously for the possession of territory. The females, arriving soon after the males have established themselves, are divided up among them, in numbers varying from a dozen to a hundred to each male in extreme cases. This arrival occurs in June, and the young are born the last days of June or in the early part of fuly. The young seals remain with their mothers until the latter part of August. The seal herd lingers about the istands until late in the fall, when the annual movenent into the Pacific Ocean takes place.

The highly polygamous habit of the fur seals naturally results in a large surplus of males, which surplus, when the rookeries were in their best condition, amounted to about 100,000 immature males a year on the Pribilofs and over 35,000 a year on the Commanders. These half-grown males herd by thenselves, on so-called "hauling grounds" adjacent to each breeding rookery, and it is from them that the annual catch on the islands has always been made. The seals are quietly surrounded, and without difficulty are driven inland, entirely away 
from the rookeries of breeding seals, as easily as a band of sheep. They are killed and skinned by the natives, the skins are counted by government agents, and are then placed in the salt houses of the lessees of the islands for a month's curing, when they are shipped to London, which has always been the world's fur-seal market. The selecting and killing are accomplished without noise or disturbance, and everything is done decently and in order. The United States and Russian Governments have never allowed any disturbing of the breeding rookeries and have never permitted the killing of female seals. The breeding stock upon the islands has therefore renained undisturbed, and would, but for the international nuisance of pelagic sealing, have yielded forever a world supply of sealskins.

Pelagic sealing, however, practiced in the open sea both in and out of season, permits of no selections being made, and the catch consists of young and old, male and female. By far the greater portion, however, is female seals, for these, after the young are bom, go to sea to feed, ranging as far as 200 miles from the islands and returning at more or less regular intervals to nurse their young. The killing of females at this season is followed by the starvation of all nursing young on the breeding grounds, the loss of young in this manner corresponding with the number of mother seals taken by the sealing vessels. In ten years pelagic sealing in the adjacent waters and in the Pacific Ocean destroyed the value of the Pribilof and Commander islands as government properties. The seal herds are now so decimated that the surplus males available for killing on the Pribilof Islands are less than half as many as in 1896.

Pelagic sealing at the present time is engaged in by ressels belonging to British Columbia and to Japan. The British Columbia fleet has greatly diminished in numbers as the seals have become fewer and it found the profits less, but there has been an increasing number of Japanese sealers in recent years, until in I gos the latter fleet numbered 38 vessels, which took 13,197 skins. 'The British Columbia fleet in that year numbered 8 vessels, and took 4,452 skins. This total of 17,649 skins is, however, a great decrease from the pelagic catch of 61,838 skins in 1894 , and shows the results of the indiscriminate slaughter.

So long as pelagic or indiscriminate sealing in any form remains, the restoration of the fur-seal fisheries will be impossible. The Bering Sea controversy was precipitated by the seizure by the United States Goveriment of Canadian sealing vessels in Bering Sea. Later on, the matter was placed in the hands of the Tribunal of Arbitration at Paris. This tribunal having decided that the United States had no jurisdiction over Bering Sea outside of territorial limits, pelagic sealing continued in but slightly modified form. Renewed efforts have been made by the United States Govermment to put a stop to it, however. American citizens, a small number of whom were engaged in pelagic sealing, 
have been prohibited from engaging in the pursuit of seals at sea, and Congress has passed laws prohibiting the importation of skins taken by pelagic sealing into the United States.

The seals taken at sea are shot or speared, and the skins, thus injured, are consequently less valuable than the land catch. The class of skins obtained under government direction on the Pribilof and Commander islands is of the highest quality, the animals selected being 3-year-old males of nearly uniform size, killed when the fur is in best condition. This catch in agos amounted to $14.96+$ skins, which sold at an average of $\$ 30$ per skin. 

LIBRARY OF CONGRESS

Hollinger Corp. pH 8.5 